
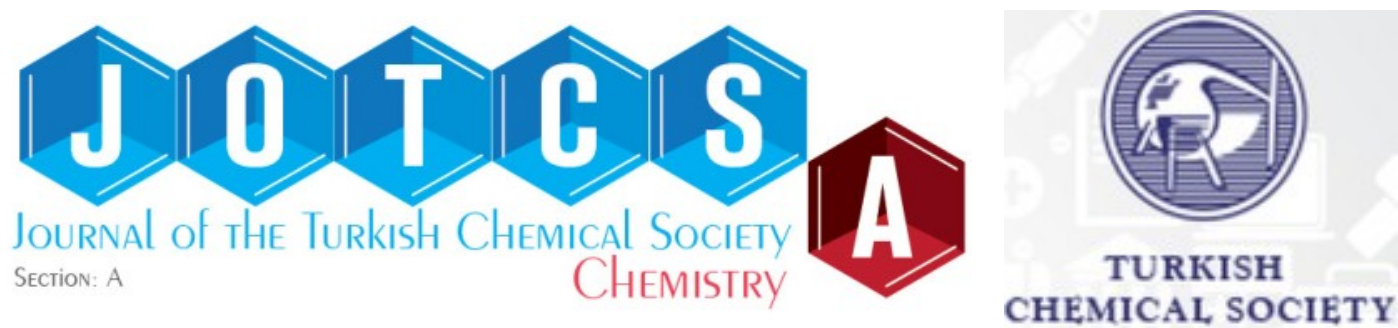

\title{
Synthesis and Characterization of the Molecularly Imprinted Composite as a Novel Adsorbent and its Competition with Non-Imprinting Composite for Removal of Dye
}

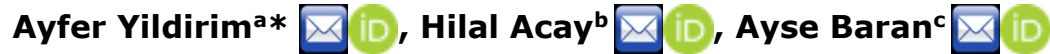 \\ $a^{*}$ Mardin Artuklu University, Vocational School of Health Services, 47200 Mardin/Turkey \\ ${ }^{b}$ Department of Nutrition and Dietetics, School of Health, Mardin/Turkey \\ cMardin Metropolitan Municipality, Artuklu, Mardin/Turkey
}

\begin{abstract}
Due to its high visibility, high resistance, and toxic effects, colored substances in the textile and other dyeing industries waste-water cause great damage to biological organisms and ecology. Therefore, current research efforts to develop high selectivity, specificity, and efficient water treatment technologies are very intense, and molecularly imprinting methods (MIM) constitute a category of functional materials to meet these criteria. Polymethylmethacrylate-chitosan molecularly imprinted composite (PMMAC-MIC) and non-imprinted composite (PMMAC-NIC) were successfully prepared by MIM. Dye adsorption performance of MIC and NIC composites was investigated by comparison. The obtained adsorbents were characterized by Fourier transform infrared spectroscopy (FTIR), X-ray diffraction (XRD), field-emission scanning electron microscopy (FE-SEM), differential scanning calorimetry (DSC), thermogravimetric analysis (TGA), and zeta potential techniques. The kinetics of adsorption followed a pseudo-first-order model while the Langmuir adsorption isotherm provided the best fit. The maximum adsorption capacity of dye was found as $93.78 \mathrm{mg} / \mathrm{g}$ for PMMAC-MIC and $17.70 \mathrm{mg} / \mathrm{g}$ for PMMAC-NIC at $298 \mathrm{~K}$ temperature, the initial dye concentration was $100 \mathrm{mg} / \mathrm{L}$. Thermodynamic parameters indicated that the removal of dye from PMMAC-MIC was endothermic and spontaneous. Besides, the regeneration of composite was recycled four times.
\end{abstract}

Keywords: Molecular imprinting, adsorption, composite, regeneration, selectivity.

Submitted: January 25, 2021. Accepted: April 30, 2021.

Cite this: Yildirim A, Acay H, Baran A. Synthesis and Characterization of the Molecularly Imprinted Composite as a Novel Adsorbent and its Competition with Non-Imprinting Composite for Removal of Dye. JOTCSA. 2021;8(2):609-22.

DOI: https://doi.org/10.18596/jotcsa.868054.

*Corresponding author. E-mail: ayferyildirim@artuklu.edu.tr.

\section{INTRODUCTION}

With the development of industrialization, the use of dyes, which endangers the living organisms, in textile and other dyeing sectors e.g. plastic, paper, foods, pulp, color photographs, cosmetics has been increasing in recent years. As a result of textile wastes being released, the waters are rapidly exposed to pollution day by day (1). Also, dyes are the most dangerous pollutants in wastewater because of their permanence and high hazardous properties. Malachite green (MG) is an important cationic textile dye that is widely used because of its strong effect on antimicrobial, antifungal, antiparasitic, and antibacterial effects. However, due to its acute and persistent toxicity, this dyestuff exposes aquatic and territorial organisms to mutagenic, teratogenic, and carcinogenic effects (2). At this point, drinking water industries focus their efforts on the development of new technologies to remove various persistent pollutants from water sources. Many physical and physicochemical methods such as coagulation/flocculation, chemical oxidation, 
ozonation, ultra-filtration, membrane, and photoseparation processes have been developed for the removal of dyes from aqueous solution (3). However, adsorption is a highly effective and lowcost preferred technique for removing dyestuff from contaminated water. A recent study focuses on both efficient composites and recognized methods (4).

The molecular imprinting method (MIM) for dyes is mainly used as adsorbents for solid-phase extraction due to their high selectivity in complex samples. MIM ensures cost-effective and easyhandling for the selective removal of certain water pollutants. Owing to these pressure holes, the target pollutant molecules are adsorbed very easily since they are defined according to the structure of the template molecule (5). Recently, the imprinting method has been of great interest in the development of chromatographic adsorbents, sensors, membranes, enzymes, and receptor mimetics.

Chitosan is one of the most abundant biological substances (natural polysaccharides) in nature. It has great biological and chemical properties as nontoxicity, low-cost, intelligent, biocompatible, biodegradable, and hydroxyl and amine functional groups on its structure. All these important features make chitosan a very interesting ingredient that can be preferred in removing dyes from the aqueous wastewater system $(6,7)$. A lot of dye-imprinted chitosan have shown great promise for preparing materials and recognition of target dyes in the past regarding the economic feasibility and environmental importance of it. Because of the easy dissolution in acidic media $(\mathrm{pH}<6.0)$, weak mechanical strength, and low surface area of chitosan, innovative physical and chemical modifications like crosslinked or composite formation can be developed to overcome these limitations. Thus, higher adsorption capacity and better mechanical properties can be achieved by different composite material formations. The preference of polymethylmethacrylate (PMMA) in this study is that it can easily interact with chitosan by forming hydrogen bonds, and it is a common polymer that has high mechanical strength and good acid fastness that will increase the strength and stability of the composite.

There are many studies reported in the literature about the MIM method for the adsorption of dyes with composites based on chitosan. For example, Deng et al., (8) prepared the Lewis acidfunctionalized-crosslinked chitosan as a sorbent for active brilliant red $(\mathrm{X}-3 \mathrm{~B})$ dye. Crosslinked-chitosan and $\beta$-cyclodextrin were used as an adsorbent for Remazol Red (9). Epichlorohydrin and glutaraldehyde magnetic chitosan were prepared for the adsorption of chalcone dye (10). Chitosan- $\mathrm{TiO}_{2}$ nanocomposite was prepared for the selective and quantitative removal of Rose Bengal dye (11). The adsorption performance of Acid Blue 113 was investigated by cross-linked polyacrylamide grafted /chitosan hydrogels (12). In another previous study, zeolitic imidazolate framework /chitosan/polyvinyl alcohol composite membrane adsorbents were performed for the removal of malachite green dye (13). Lulu et al. have prepared a chitosan/magnetite and used alizarin red as template dye (14).

The main purpose of this study is to synthesize the polymethylmethacrylate-chitosan composite to join the selectivity advantages of MIM and investigate the removal of malachite green (MG) dye using the molecular imprinting method with a comparison with the non-imprinting method. In the adsorption studies, kinetic studies were carried out by using pseudo-first and pseudo-second kinetic models with the effects of initial dye concentration, $\mathrm{pH}$, and temperature. Besides, thermodynamic parameters were predicted by using Langmuir and Freundlich isotherms. The regeneration feature was made to provide an economic contribution to the study. Also, the selectivity experiment for PMMAC-MIC-MG was analyzed with methylene blue (MB) as a cationic dye and reactive orange 25 (RO16), acid blue 25 (AB25) as anionic dyes.

\section{MATERIALS AND METHODS}

\section{Materials and Chemicals}

The methylmethacrylate (MMA, Mw: $100.12 \mathrm{~g} / \mathrm{mol}$ ), ethylene glycol dimethacrylate (EGDMA, $\mathrm{M}_{\mathrm{w}}: 198.22$ $\mathrm{g} / \mathrm{mol}$ ), ammonium persulfate (APS, Mw: 228 $\mathrm{g} / \mathrm{mol}$ ), malachite green oxalate (MG, $\mathrm{C}_{52} \mathrm{H}_{54} \mathrm{~N}_{4} \mathrm{O}_{12}$, $\mathrm{M}_{\mathrm{w}}: 927 \mathrm{~g} / \mathrm{mol}$ ) and chitosan ( $\mathrm{C}$, medium molecular weight) were supplied by Sigma-Aldrich.

\section{Synthesis of PMMAC-MIC and PMMAC-NIC Composites}

In the initial process of preparing the PMMAC-MIC, briefly, $200 \mathrm{mg}$ of chitosan was dissolved by $1 \%, 30$ $\mathrm{mL}$ acetic acid in a flask for 2 hours. Then, 49.35 $\mathrm{mg}$ of MG, $0.42 \mathrm{~mL}$ of MMA was dissolved in $10 \mathrm{~mL}$ of ethanol and $0.4 \mathrm{~mL}$ of EGDMA was added. After the substances were dissolved in ethanol completely, then it was poured into chitosan solution. Later, $148 \mathrm{mg}$ APS was transferred into the mixture and then stirred for $4 \mathrm{~h}$ at $80{ }^{\circ} \mathrm{C}$. The obtained solution was added dropwise into $0.1 \mathrm{M}$ $\mathrm{HCl}$ and filtered to remove the MG ions. Finally, the unreacted materials were removed by washing the composite with distilled water and ethanol, and the resulting composite particles were dried at about 90-100 ${ }^{\circ} \mathrm{C}$. The nonimprinted composite (PMMACNIC) was prepared in the same way, but without the addition of MG during preparation.

\section{Characterization of Composites}

To examine the characterization of composite, FTIR analysis of PMMAC-MIC and PMMAC-NIC, PerkinElmer Spectrum 100 model ATR-FTIR apparatus 
(wavenumber range: $4000-400 \mathrm{~cm}^{-1}$ ) was used. XRD patterns of the composites were examined by Rigaku Ultima-IV model device. FE-SEM was used for the investigation of the morphological structure of composites with the model Quanta 400F apparatus. Thermal behavior of composites was employed by DSC measurements on a DSC250 TA instrument with $10{ }^{\circ} \mathrm{C} \mathrm{min}^{-1}$ heating rate under a nitrogen atmosphere and TGA on SDT650 model with the analyzes performing in the range from 25 to $950^{\circ} \mathrm{C}$, the heating rate of $10^{\circ} \mathrm{C} 1 / \mathrm{min}$, nitrogen atmosphere with a flow rate of $100 \mathrm{~mL} / \mathrm{min}$. The Zeta potential was analyzed by a Zetasizer (Malvern Nano ZS90 Zetasizer).

\section{Adsorption Experiments}

The adsorption ability of PMMAC-MIC and PMMACNIC was investigated by batch adsorption technique. The contact time, effect of $\mathrm{pH}$ and temperature, kinetics and isotherms of adsorption were studied. For the preparation of the stock dye solution, 100 $\mathrm{mg}$ of MG dye was dissolved in $1 \mathrm{~L}$ of distilled water. To make batch experiments, $10 \mathrm{mg}$ of composites were shaken with a $20 \mathrm{~mL}$ dye solution with a shaking speed of $120 \mathrm{rpm}$ (GFL 1083) and pH (5) at $298 \mathrm{~K}$ for $300 \mathrm{~min}$. The concentration of dye solution was examined by PG T80+ model UV-Vis spectrophotometer at $617 \mathrm{~nm}$. The adsorption capacity and percent adsorption were calculated with the below equations (Eq. 1,2), respectively (15).

$$
\begin{aligned}
q & =(C o-C e) * \frac{V}{m} \\
\% \text { adsorption } & =\frac{C o-C e}{C o} * 100
\end{aligned}
$$

Where $q(\mathrm{mg} / \mathrm{g})$ presents the adsorption capacity, $C_{o}$ and $C_{e}(\mathrm{mg} / \mathrm{L})$ are the initial and equilibrium concentrations of MG, $V(L)$ refers to the volume of the solution, and $m(\mathrm{mg})$ is the amount of the composites. Experimental studies were made in 2 repetitions and error bars were shown in the figures.

\section{Regeneration Studies}

Some of the conditions for the composite regeneration mentioned in the literature (16) were carried out with a little modification as follows: 20 $\mathrm{mL}, 100 \mathrm{mg} / \mathrm{L}$ MG dye solution was contacted with $10 \mathrm{mg}$ of PMMAC-MIC composite for $180 \mathrm{~min}$ at 298 $\mathrm{K}$ and $\mathrm{pH}$ 8. The composite particles were filtered and the amount of adsorbed dye was analyzed by a UV-spectrophotometer $(617 \mathrm{~nm})$. The charged adsorbent was completely washed with distilled water, filtered, and transferred to a flask involving the $0.1 \mathrm{M} \mathrm{HCl}$ desorbing agent and shaken for 180 min at $298 \mathrm{~K}$. This study was repeated four times. The amount of desorbed MG dye was calculated by the following equation (Eq. 3):

$$
\text { Dye ads . \% }=\frac{\text { amt. desorbed from ads }}{\text { amt desorbed onto ads }} \times 100
$$

\section{Selectivity Experiments}

To investigate the selectivity of the MG dye, a cationic dye MB and two anionic dyes RO16, AB25 were used (structures are shown in Figure 1). Besides, the percentages of binding of these dyes were investigated by comparison with the MG dye and plotted graphically. For the experimental studies, $20 \mathrm{~mL}$ of the initial concentration of 50 $\mathrm{mg} / \mathrm{L}$ of each dyestuff was prepared and poured into a $100 \mathrm{~mL}$ flask, $10 \mathrm{mg}$ of adsorbent was then added to each flask and shaken at $120 \mathrm{rpm}$ in the shaking water bath for 180 minutes. The final supernatants of MB, RO16, AB25 dyes were performed by a UVVis spectrophotometer at the maximum absorption wavelengths at $664 \mathrm{~nm}, 505 \mathrm{~nm}, 610 \mathrm{~nm}$, respectively.

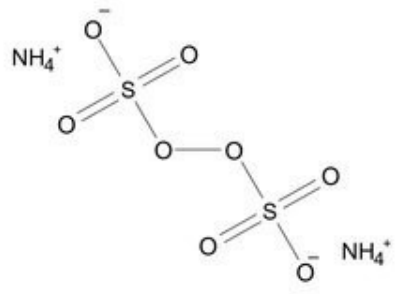

(a)<smiles>C=C(C)C(=O)OC</smiles>

(b)

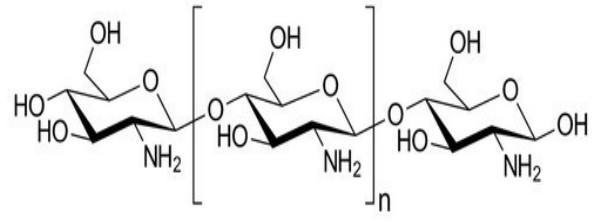

(c) 
<smiles>C=C(C)C(=O)OCCOC(=O)C(=C)C</smiles>

(d)<smiles>CC(=O)Nc1ccc2c(O)c(N=Nc3ccc(S(=O)(=O)COS(=O)(=O)O)cc3)c(O)c(O)c2c1</smiles>

(g)<smiles>CN(C)c1ccc(C(c2ccccc2)c2ccc([N+](C)C)cc2)cc1</smiles>

(e)<smiles>CN(C)c1ccc2nc3ccc(=[N+](C)C)cc-3sc2c1</smiles>

(f)<smiles>COS(=O)(=O)c1cc(Nc2ccccc2)c2c(c1N)C(=O)c1ccccc1C2=O</smiles>

(h)

Figure 1: Chemical structures of (a) ammonium persulfate (APS), (b) methyl methacrylate (MMA), (c) chitosan, (d) ethylene glycol dimethacrylate (EGDMA), (e) malachite green (MG), (f) methylene blue (MB), (g) reactive orange 25 (RO16), (h) acid blue 25 (AB25).

\section{RESULTS AND DISCUSSION}

\section{Characterization}

FTIR analysis

FTIR spectra of PMMAC-MIC, PMMAC-NIC composites are illustrated in Figure 2a. As can be seen from Figure 2a, there are peaks at 2988, 2951, 2988, and $2952 \mathrm{~cm}^{-1}$ in the PMMAC-NIC and PMMAC-MIC spectrum corresponding to the stretching vibration peak of the saturated $\mathrm{C}-\mathrm{H}$ stretching vibration, respectively (17-20). The peak in the PMMAC-NIC spectrum at $1724 \mathrm{~cm}^{-1}$ and in the PMMAC-MIC spectrum at $1722 \mathrm{~cm}^{-1}$ demonstrated the carbonyl group of the ester group of PMMA.

It is probable that there is no peak related to the characteristic bands of the MG dye (template) in the
PMMAC-MIC spectra as the peak belongs to the aromatic ring at $1560-1580 \mathrm{~cm}^{-1}$ which demonstrate the purification of MIC composite from MG template dye molucules (Figure 2a) (21). The peaks observed at 1449, 1451, and $1387 \mathrm{~cm}^{-1}$ are bending vibrations of $\mathrm{CH}_{2}$ and $\mathrm{CH}_{3}$ also, the peak at 1144, $1142 ; 750,752 ; 962$, and $953 \mathrm{~cm}^{-1}$ correspond to the vibration of $\mathrm{CO} ; \mathrm{CH}_{2} ; \mathrm{CC}$ stretching in the spectra of PMMAC-NIC and PMMAC-MIC, respectively (22). As a result, it can be demonstrated that differences between peaks in the PMMAC-NIC and PMMAC-MIC FTIR spectra may also be based on the spaces between the functional groups caused by the removal of MG dye molecules from the structure by the imprinting method. 


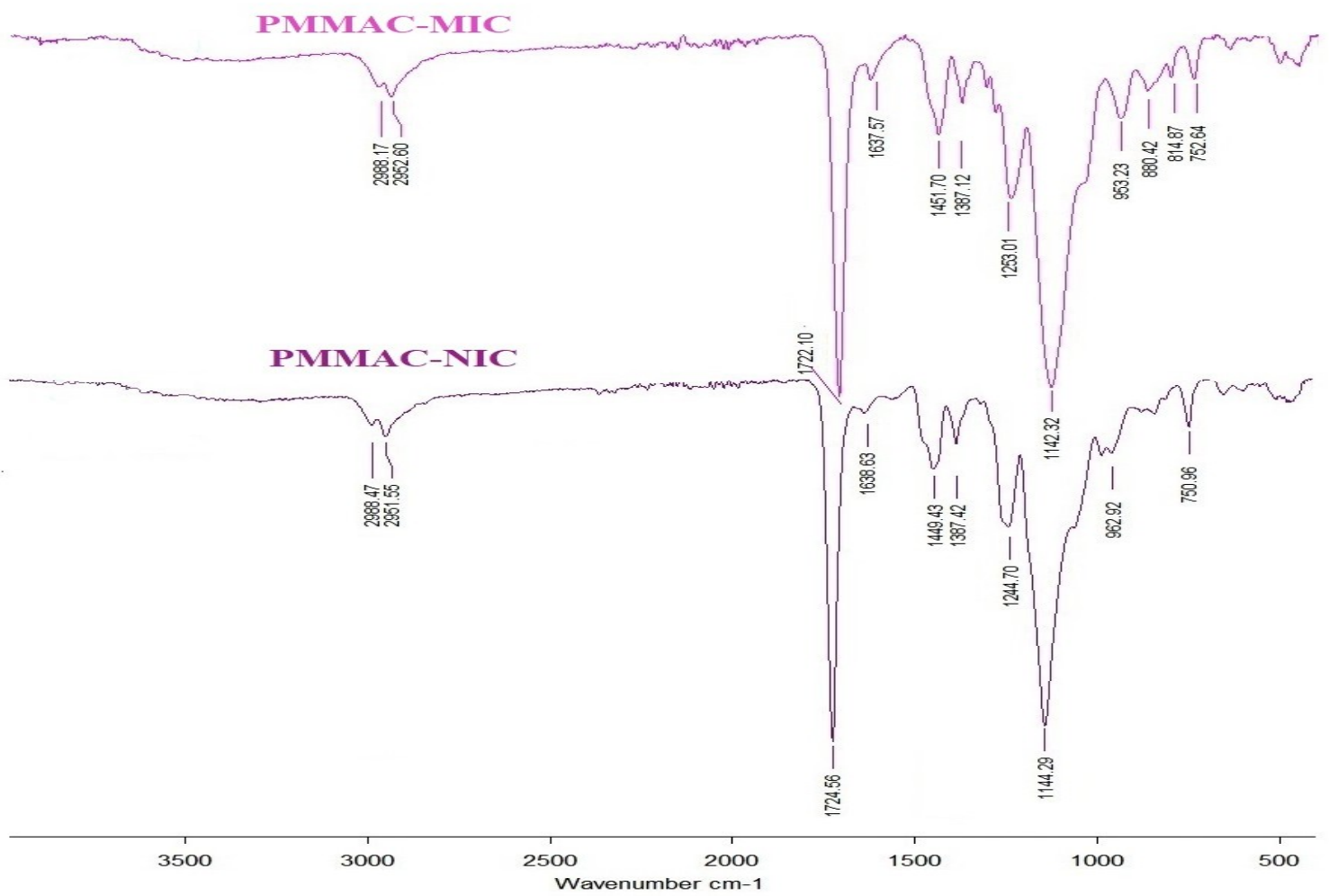

(a)

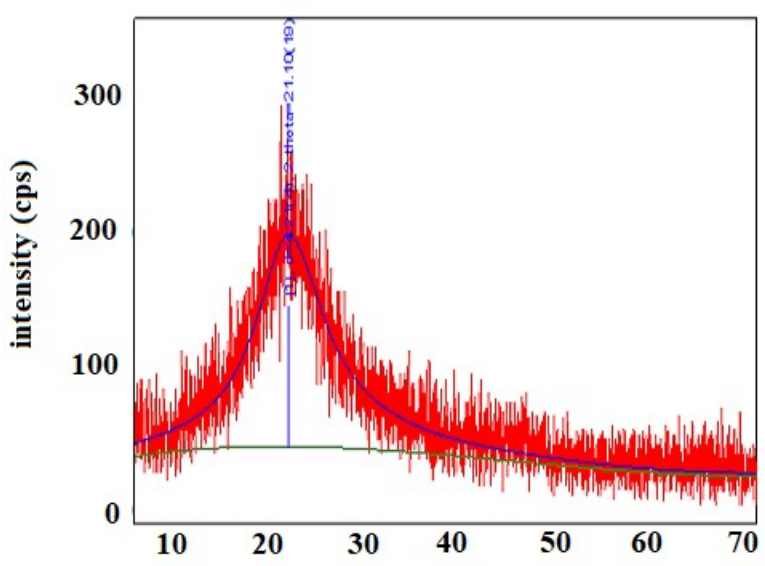

(b)

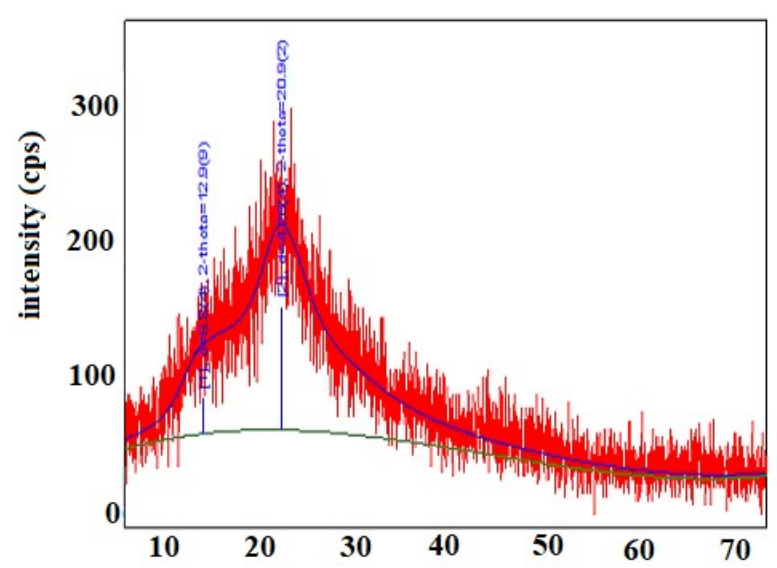

(c) 


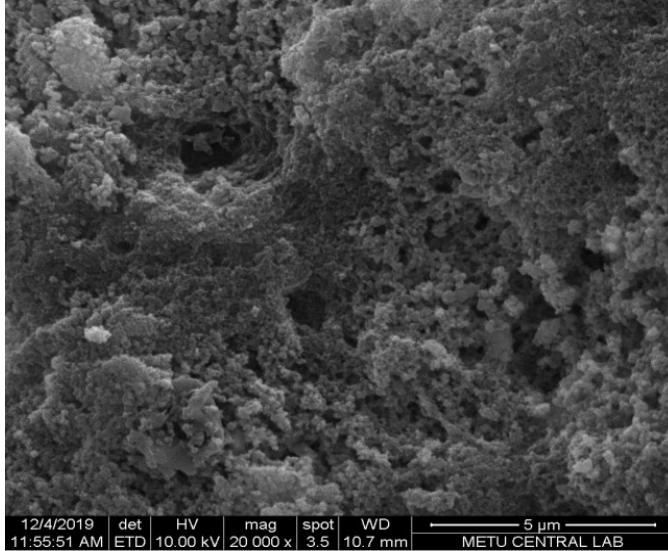

(d)

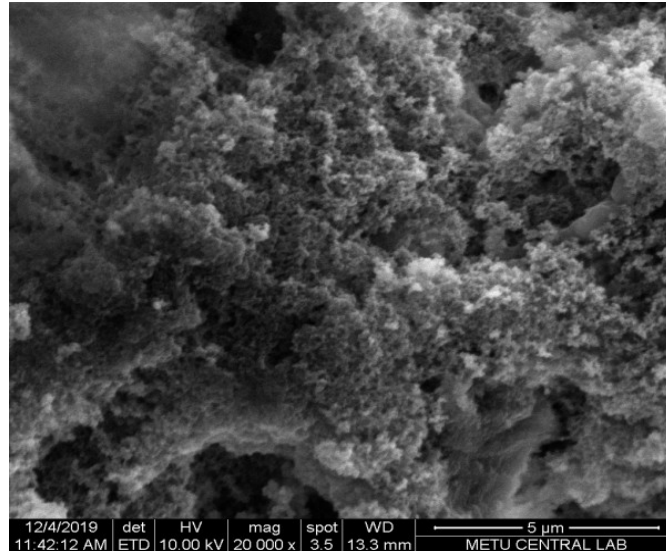

(e)

Figure 2: FTIR spectra of PMMAC-MIC and PMMAC-NIC (a), XRD patterns of PMMAC-MIC (b) PMMAC-NIC (c), SEM images of PMMAC-MIC (d), PMMAC-NIC (e).

\section{$X R D$ analysis}

The XRD patterns that indicate the crystallinity of composites of PMMAC-NIC and PMMAC-MIC were depicted in Figure $2 \mathrm{~b}$ and $2 \mathrm{c}$ (23). The characteristic peaks of chitosan 2-theta degree were recorded at $21.10^{\circ}, 20.9^{\circ}$ for PMMAC-MIC and PMMAC-NIC, respectively. The XRD patterns revealed the successful differences between PMMAC-MIC and PMMA-NIC which may be caused by the removal of dye template molecules. The crystallite sizes of the PMMAC-MIC and PMMA-NIC were found at $9.50 \mathrm{~nm}$ and $11.0 \mathrm{~nm}$, respectively as the results obtained from XRD analysis.

\section{SEM analysis of composites}

The morphologies of PMMAC-NIC and PMMAC-MIC were studied by scanning electron microscope. The results of SEM images are depicted in Figure $2 \mathrm{~d}$ and $2 e$. It can be observed in Figure $2 d$ and $2 \mathrm{e}$, the surface morphology of the PMMA-MIC composite is different from the PMMA-NIC composite. The SEM image of the MIC composite is predicted to be more rough, orderly, and stable than that of the NIC

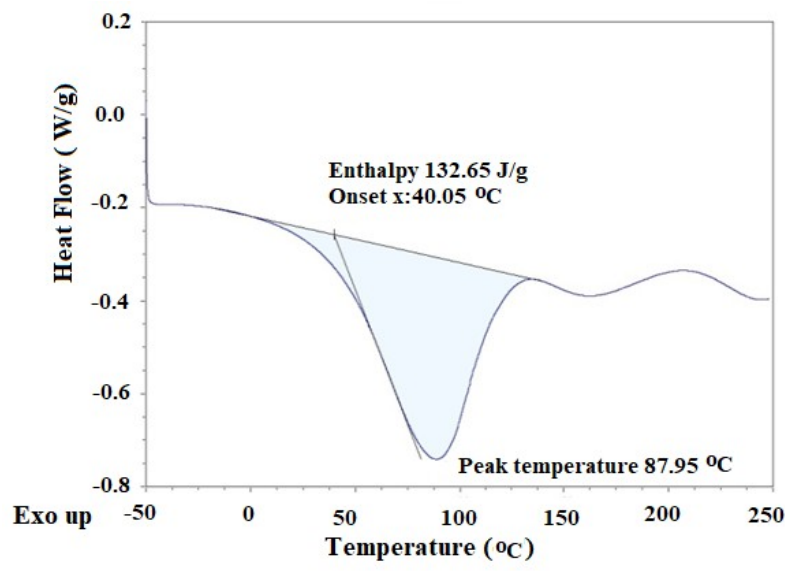

(a) composite, which may be caused by voids created by removing imprinted $M G$ dye molecules on its surface $(24,25)$. Besides, it is predicted that the SEM image of the MIC composite was more porous than that of the NIC composite and that this porosity of the MIC composite may account for better adsorption capacity for MG dye.

\section{DSC analysis}

DSC profiles of PMMAC-MIC and PMMA-NIC are depicted in Figure $3 a$ and $3 b$. DSC was used to determine the phase behavior and thermal transitions of PMMAC-MIC and PMMAC-NIC (Figure $3 a$ and $3 b)$. According to the results, the endothermic peak of PMMAC-NIC was located at $87.95{ }^{\circ} \mathrm{C}$ (Figure 3a). PMMAC-MIC composite indicated three endothermic peaks at $59.92{ }^{\circ} \mathrm{C}$, $230.95{ }^{\circ} \mathrm{C}$, and $293.68{ }^{\circ} \mathrm{C}$, respectively which suggests that the surface modification was formed and the thermal stability was improved by increasing the temperature (supporting the increasing thermal resistance) after the imprinting process (Figure 3b) (26).

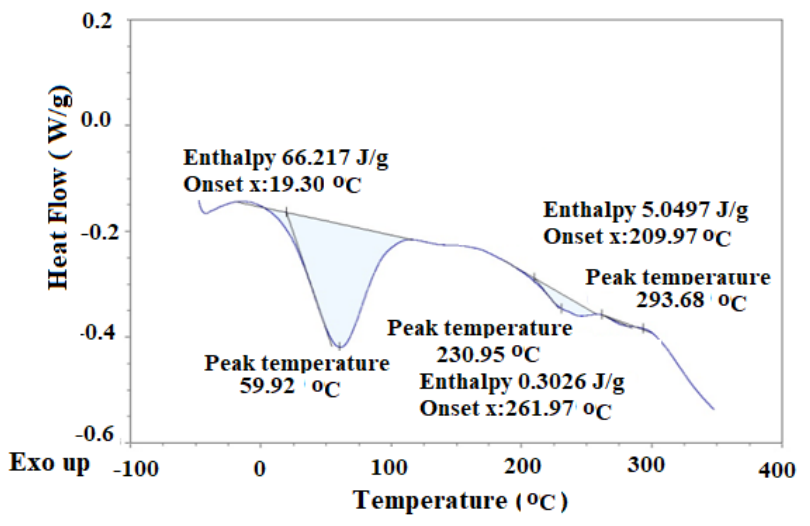

(b) 


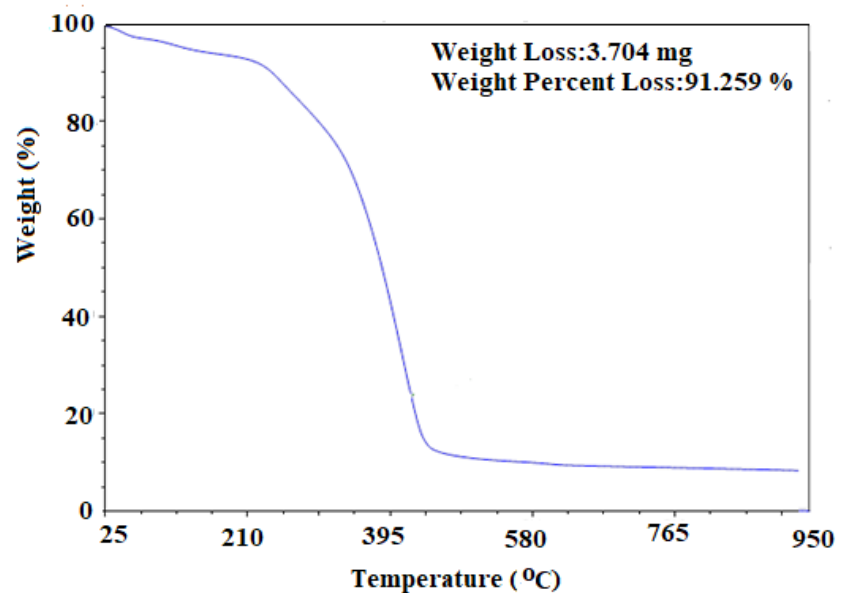

(c)

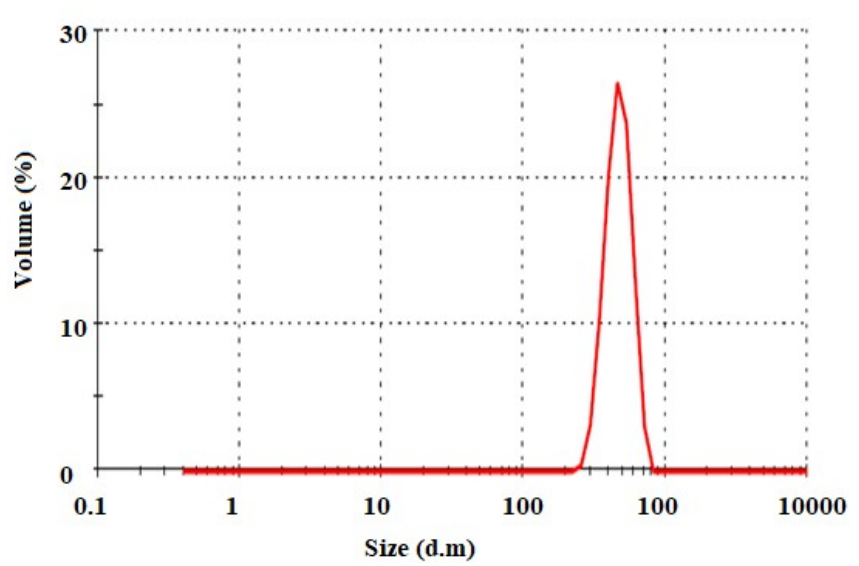

(e)

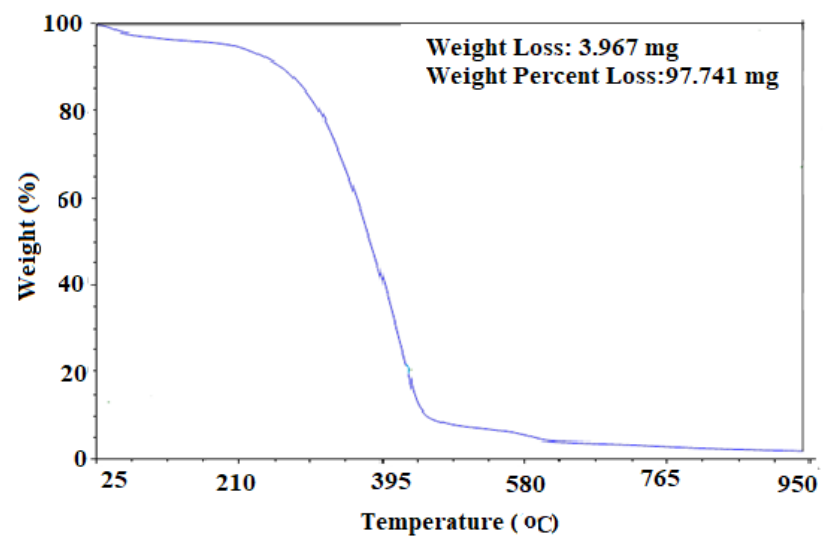

(d)

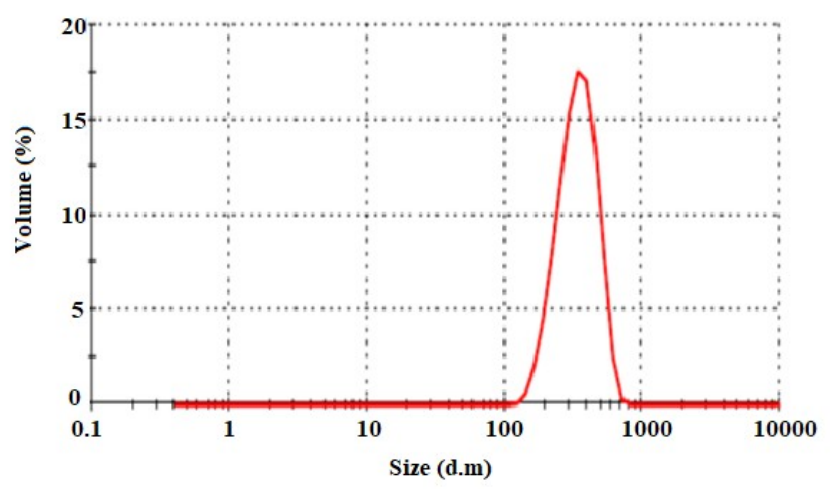

(f)

Figure 3: DSC thermogram of (a) PMMAC-NIC (b) PMMAC-MIC, TGA analysis of (c) PMMAC-NIC (d) PMMAC-MIC, size distribution of (e) PMMA-NIC, (f) PMMA-MIC.

TGA analysis of the composites

The thermal stability and degradation profile of the composites were assessed by thermogravimetric analysis (27). Figure $3 c$ and $3 d$ exhibited the TGA curves of the PMMAC-NIC, PMMAC-MIC that exhibited the amount of mass loss and its percent of PMMAC-NIC, PMMAC-MIC were $3.704 \mathrm{mg}, 3.987 \mathrm{mg}$, and $91.259 \%, 97.741 \%$, respectively. Below $200{ }^{\circ} \mathrm{C}$ the mass losses have pertained to the polar groups or moisture in the composites (28). The mass losses between $0-100{ }^{\circ} \mathrm{C}$ indicated the evaporation of moisture in the samples (29). The results showed that the thermal stability of the MIC composite was better than NIC adsorbent slightly due to the addition of dye adsorbed, which also confirmed the successful imprinting of dye ions. A similar result has been found by Lewandowska et al., (30) in which the SBF-treated chitosan composite was investigated (Sohni et al., 2019).

\section{Zeta potential analysis}

Zeta potential measurement is used to describe the charge performance of the nanoparticle surface (31). Figure $3 e$ and $3 f$ show the size distribution of PMMA-NIC and PMMA-MIC, respectively. The particle size obtained of the PMMA-NIC particles is about $860.3 \mathrm{~nm}$ while the PMMA-MIC particle $449.0 \mathrm{~nm}$. The positive Zeta potential value of both the MIC (40.3 $\mathrm{mV}$ ) and the NIC (30.2 mV) composite indicates that the surface of both composites is predominantly loaded with a positive charge. Also, the fact that both PMMA-NIC (0.777) and PMMA-MIC $(0.473)$ composites have PDI values greater than 0.2 , explains that the composite surfaces are heterogeneous.

\section{Effect of pH and Point of Zero Charge ( $\left.P_{\mathrm{pzc}}\right)$}

$\mathrm{pH}$ has an absolute impression on the adsorption capacity as it changes the surface properties of the composite due to the ionization of the degree of dye molecules for the adsorption process. Figure $4 a$ 
illustrates that the percent adsorption capacity of MG dye on PMMAC-MIC adsorbent increased by raise of $\mathrm{pH}$ in the range of $2-8$. At low $\mathrm{pH}$, since the zero-point charge of the adsorbent was found to be $6.3(\mathrm{pH}<\mathrm{pHzpc}$, Figure 4b), the surface of the adsorbent becomes positively charged and protonation occurs on the surface of the adsorbent with the functional groups. Nonetheless, the electrostatic contradiction between cationic dye molecules and positively charged adsorbent is formed and so, the adsorption capacity of MG dye is reduced. In contrast, at the higher $\mathrm{pH}$, above zeropoint charge $(\mathrm{pH}>\mathrm{pHzpc})$, the adsorbent surface becomes negatively chargeable leading to electrostatic interaction between adsorbent and cationic dye, resulting from an increase in adsorption capacity.

\section{Effect of Contact Time and Initial Dye Concentrations}

The adsorption of MG dye by PMMAC-MIC and PMMAC-NIC is shown in Figure 4c. In the beginning, adsorption rapidly increases and reaches equilibrium at $180 \mathrm{~min}$ for both NIC and MIC composites. Initially, the adsorption was rapid due to the availability of abundant vacant adsorption sites, then the adsorption slowed down as they reached

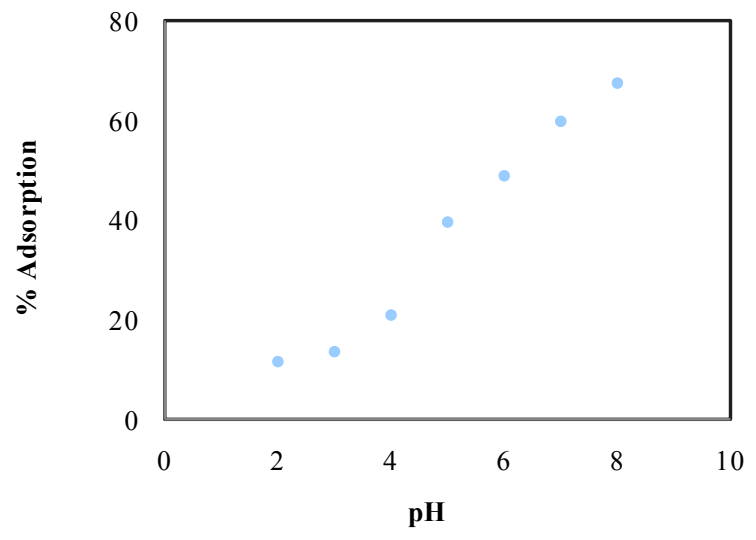

(a)

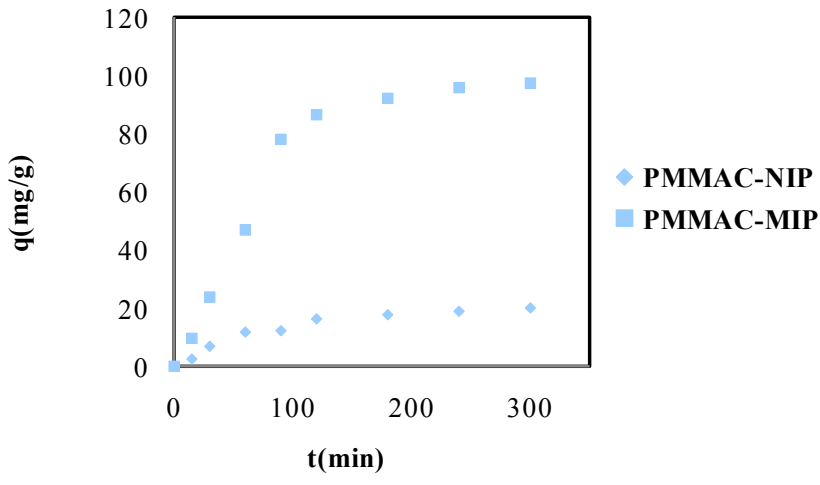

(c) saturation. As seen in Figure 4c, the adsorption capacity of PMMAC-MIC (93.78 $\mathrm{mg} / \mathrm{g})$ was much higher than PMMAC-NIC $(17.70 \mathrm{mg} / \mathrm{g})$. This was verifying the enhancement of suitable coordinations between the MIC and MG dye.

To investigate the effect of the initial dye concentration, three initial MG dye concentrations $\left(C_{o}=50,75,100 \mathrm{mg} / \mathrm{L}\right)$ were used at $\mathrm{pH} 8$. Adsorption of both PMMAC-MIC and PMMAC-NIC increased when initial MG dye concentration increased. When initial dye concentration increased from $50 \mathrm{mg} / \mathrm{L}$ to $100 \mathrm{mg} / \mathrm{L}$, the adsorption capacity was increased from $59.70 \mathrm{mg} / \mathrm{g}$ to $93.78 \mathrm{mg} / \mathrm{g}$ and from $10.26 \mathrm{mg} / \mathrm{g}$ to $17.70 \mathrm{mg} / \mathrm{g}$ for MIC and NIC composites, respectively. These results prove that the adsorption mechanism depends on the initial concentration of dyestuff and the formation of many suitable centers on the surface of the templated adsorbent (PMMAC-MIC). Thus, the molecular imprinting adsorbent (PMMAC-MIC) could be an excellent adsorbent for the removal of $M G$ dye from aqueous solutions comparing with the nonimprinting adsorbent (PMMAC-NIC). Besides, as can be seen in Table 1, it can be interpreted that the synthesized composite is quite suitable for MG dye removal compared to previous studies.

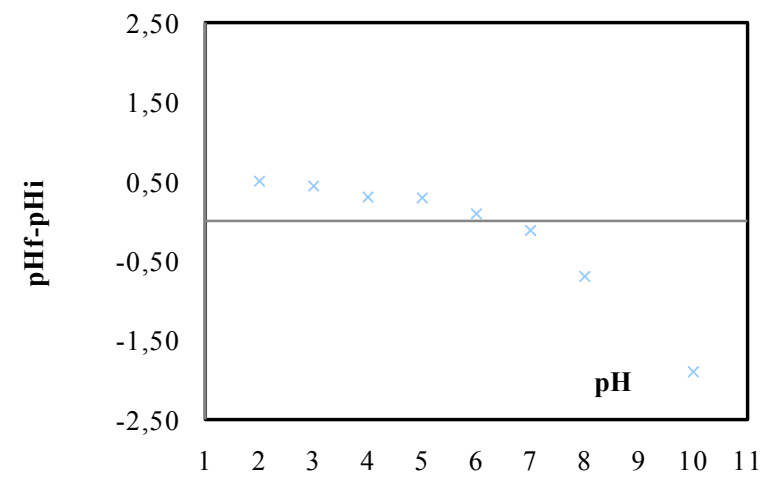

(b)

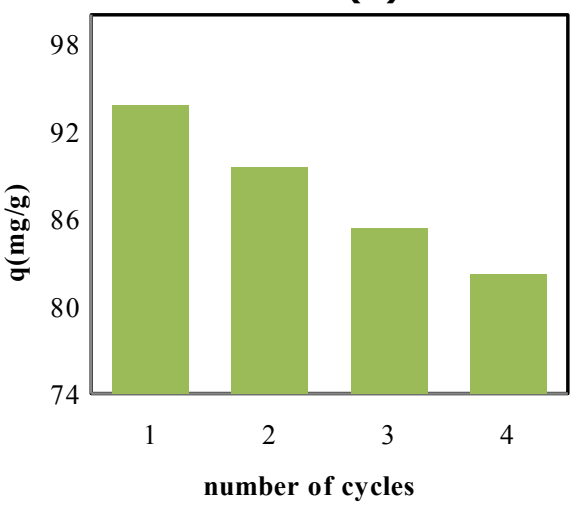

(d) 


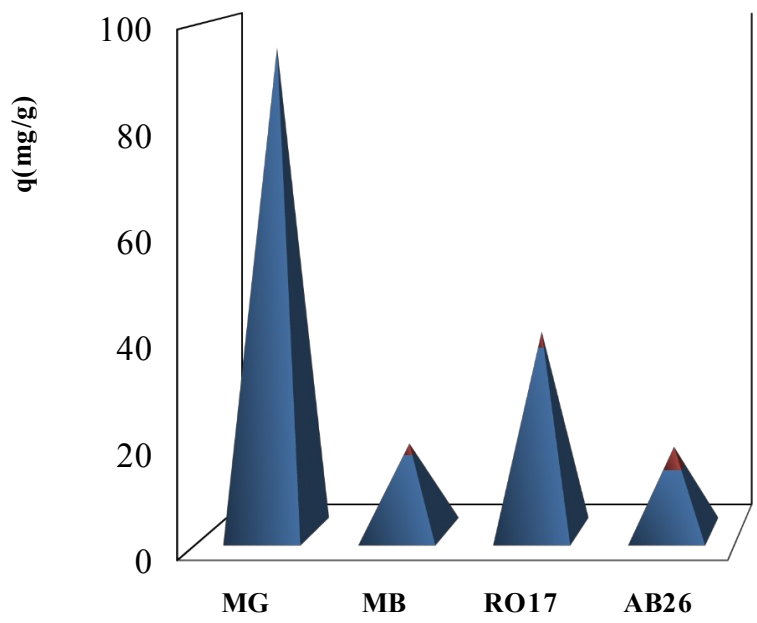

(e)

Figure 4: Effect of (a) $\mathrm{pH}$ (b) point of zero charge (c) contact time (d) regeneration (e) selectivity on MG dye adsorption.

Table 1: Adsorption capacities of various adsorbent in the literature about the MIM method for dye adsorption.

\begin{tabular}{|c|c|c|c|c|}
\hline Adsorbent & Dye & $\begin{array}{c}C_{o} \\
(\mathrm{mg} / \mathrm{L})\end{array}$ & $q_{e}(\mathrm{mg} / \mathrm{g})$ & References \\
\hline Lewis acid-crosslinked chitosan & $\begin{array}{l}\text { Active brilliant } \\
\text { red }\end{array}$ & 200 & 161.1 & $(8)$ \\
\hline Crosslinked-chitosan & Remazol red & 70 & 14.3 & $(9)$ \\
\hline $\begin{array}{l}\text { Epichlorohydrin and glutaraldehyde- } \\
\text { magnetic chitosan }\end{array}$ & Chalcone dye & 100 & $\begin{array}{l}51.71 \text { and } \\
39.23\end{array}$ & (10) \\
\hline Chitosan- $\mathrm{TiO}_{2}$ nanocomposite & Rose bengal & 64 & 79.36 & $(11)$ \\
\hline $\begin{array}{l}\text { Cross-linked polyacrylamide } \\
\text { grafted /chitosan hydrogels }\end{array}$ & Acid blue 113 & 300 & 286 & $(12)$ \\
\hline $\begin{array}{l}\text { Zeolitic imidazolate framework } \\
\text { /chitosan/polyvinyl alcohol } \\
\text { composite }\end{array}$ & Malachite green & 29.66 & 62.2 & $(13)$ \\
\hline Chitosan-magnetite & Alizarin red & 100 & 40.12 & $(14)$ \\
\hline Styrene-Methacrylate based & Malachite green & 500 & 200.00 & $(32)$ \\
\hline polymethacrylic acid & Malachite green & 250 & 303.03 & $(33)$ \\
\hline PMMAC-MIC & Malachite green & 100 & 93.78 & This study \\
\hline
\end{tabular}

\section{Adsorption Kinetics}

The kinetics of adsorption of dye onto adsorbents can be represented by the pseudo-first-order (Figure 5a) and pseudo-second-order (Figure 5b) kinetic models by the following equations, respectively (Eq.4,5) (34).

$$
\log \left(q_{e}-q_{t}\right)=\frac{\log q_{e}-k_{1}}{2.303} \times t \quad \text { (Eq. 4) }
$$

$$
\frac{t}{q_{t}}=\frac{1}{k_{2} q_{e}^{2}}+\frac{1}{q_{e} t}
$$

Where $q_{e}(\mathrm{mg} / \mathrm{g}), q_{t}(\mathrm{mg} / \mathrm{g})$ are the amount of adsorbed dye at equilibrium and time; $k_{1}(1 / \mathrm{min})$ and $k_{2}(\mathrm{~g} / \mathrm{mg} \mathrm{min})$ represent the rate constants of pseudo-first-order and pseudo-second-order, respectively, while $t$ is time.

While the pseudo-first-order kinetic model defines the first stage in adsorption, the pseudo-second, 
order kinetic model which defines the rate control mechanism is compatible with chemisorption. As is seen from Table 2, correlation coefficients $\left(R^{2}\right)$ of the pseudo-first-order model were higher than the pseudo-second model $\left(R^{2}>0.980\right)$, so the best fit model has been chosen based on the pseudo-firstorder kinetic model for adsorption of MG dye onto PMMAC-MIC composite. Also, calculated $q_{e}$ values obtained from the pseudo-first-order were closer to the experimental $q_{e}\left(q_{\exp }\right)$ values, which supports that the adsorption of the MG dye onto the PMMAC-
MIC adsorbent is more compatible with the pseudofirst-order model. The studies of noxious textile dyes adsorption onto amorphous carbon nanotubes (35) and malachite green on graphene oxide adsorption (36) have indicated similar results. According to Table 2, based on the initial concentration, the rate constant $\left(k_{1}\right)$ increase can be predicted generally by the physisorption system in MG dye adsorption onto PMMAC-MIC and PMMACNIC adsorbent surfaces.

Table 2: Kinetic data for the adsorption of MG dye onto PMMAC-MIC

\begin{tabular}{ccccccc}
\hline & \multicolumn{3}{c}{ Pseudo first order } & \multicolumn{3}{c}{ Pseudo second order } \\
\hline $\begin{array}{c}q_{\exp } \\
(\mathrm{mg} / \mathrm{g})\end{array}$ & $\begin{array}{c}q_{e} \\
(\mathrm{mg} / \mathrm{g})\end{array}$ & $\begin{array}{c}k_{1} \\
(1 / \mathrm{min})\end{array}$ & $R^{2}$ & $\begin{array}{c}q_{e} \\
(\mathrm{mg} / \mathrm{g})\end{array}$ & $\begin{array}{c}k_{2} \\
(\mathrm{~g} / \mathrm{mgmin})\end{array}$ & $R^{2}$ \\
\hline 59.70 & 65.9 & 0.014 & 0.9802 & 111.1 & 0.608 & 0.9381 \\
78.84 & 89.8 & 0.017 & 0.9806 & 120.5 & 1.044 & 0.9383 \\
93.78 & 97.3 & 0.019 & 0.9968 & 140.8 & 1.246 & 0.9693 \\
\hline
\end{tabular}

Adsorption Isotherms and Thermodynamic Parameters

The Langmuir and Freundlich isotherm models were used to describe the distribution of adsorbed dye molecules between the adsorbents and the liquid solutions at equilibrium conditions (37). The Langmuir isotherm model is the most widely used isotherm equation related to monolayered adsorption of dye molecules on the surface of the adsorbent. Langmuir isotherm model is expressed by the following equation (Figure 5c) (Eq. 6):

$$
\frac{C_{e}}{q_{e}}=\frac{1}{Q_{\max } \times K_{L}}+\frac{1}{Q_{\max }} \times C_{e}
$$

Where $q_{e}$ is the amount of MG dye adsorbed at equilibrium, $C_{e}$ is the equilibrium concentration in the aqueous solution of MG dye, $K_{L}$ is the Langmuir constant $(\mathrm{L} / \mathrm{mg})$ and $Q_{\max }$ is the maximum monolayer adsorption capacity.

The dimensionless separation factor, $R_{L}$ indicates whether the adsorption process is favorable or not is a significant parameter of the Langmuir isotherm model. The $R_{L}$ can be represented by the following equation ( $\mathrm{Eq} 7$ ).

$$
R_{L}=\left(\frac{1}{1+K_{L}}\right) \times C_{0}
$$

The adsorption process is unfavorable while the value of $R_{L}>1$, favorable when $0<R_{L}<1$, irreversible or linear when $R_{L}=0$ or $R_{L}=1$, respectively (38).

Freundlich isotherm model assumes molecules form multilayers on the adsorbent surface with adsorbed dye molecules interaction and is identified by the following equation (Figure 5d) (Eq 8) (39).

$$
q_{e}=K_{F} \times\left(\frac{C_{e}^{1}}{n}\right)
$$

Where $K_{F}$ and $1 / n$ are constants depicting the adsorption capacity and adsorption intensity, respectively.

Adsorption isotherm studies were carried out at different temperatures $T$ : 298, 308, $318 \mathrm{~K}$, six 
different initial dye concentrations $C_{0}: 25,50,75$, $100,125 \mathrm{mg} / \mathrm{L}$, equilibrium time of $180 \mathrm{~min}, \mathrm{pH}: 5$ by PMMAC-MIC adsorbent for MG dye. According to Table 3, the adsorption of MG dye by PMMAC-MIC is better described by Langmuir isotherm as correlation coefficients $\left(R^{2}>0.99\right)$ were higher compared to Freundlich throughout the ranges of initial dye concentration. The value of $K_{L}$ was decreased with rising temperature which showed that the intensity of adsorption was improved at lower temperatures. Besides, the maximum Langmuir adsorption capacity that was decreased with increasing temperature was $166.67 \mathrm{mg} / \mathrm{g}$ at $298 \mathrm{~K}$ (Table 3 ). Due to the $R_{L}$ values of PMMACMIC adsorbent at different temperatures were between 0 and 1 , the adsorption of $M G$ dye on the PMMAC-MIC is favorable. The same result was reported in a previously conducted study (40). 
Yildirim A, Acay H, Baran A. JOTCSA. 2021; 8(2): 609-622.

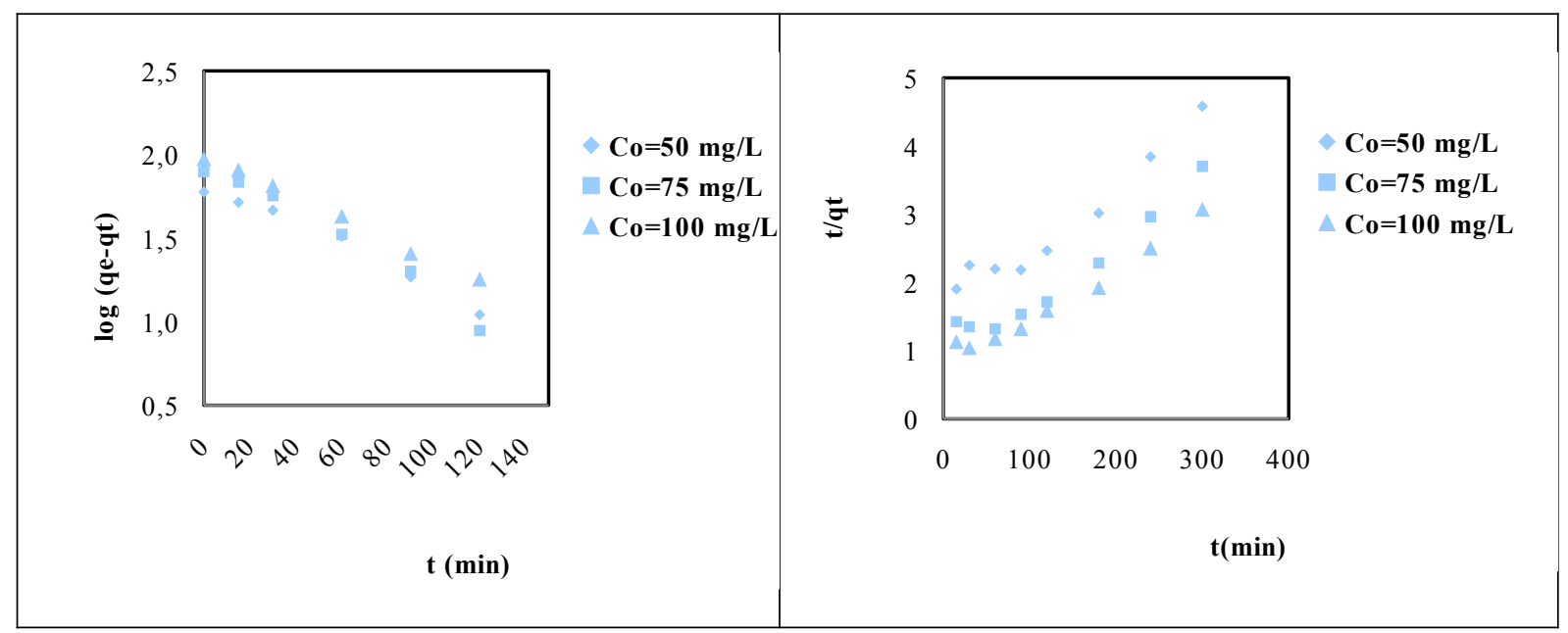




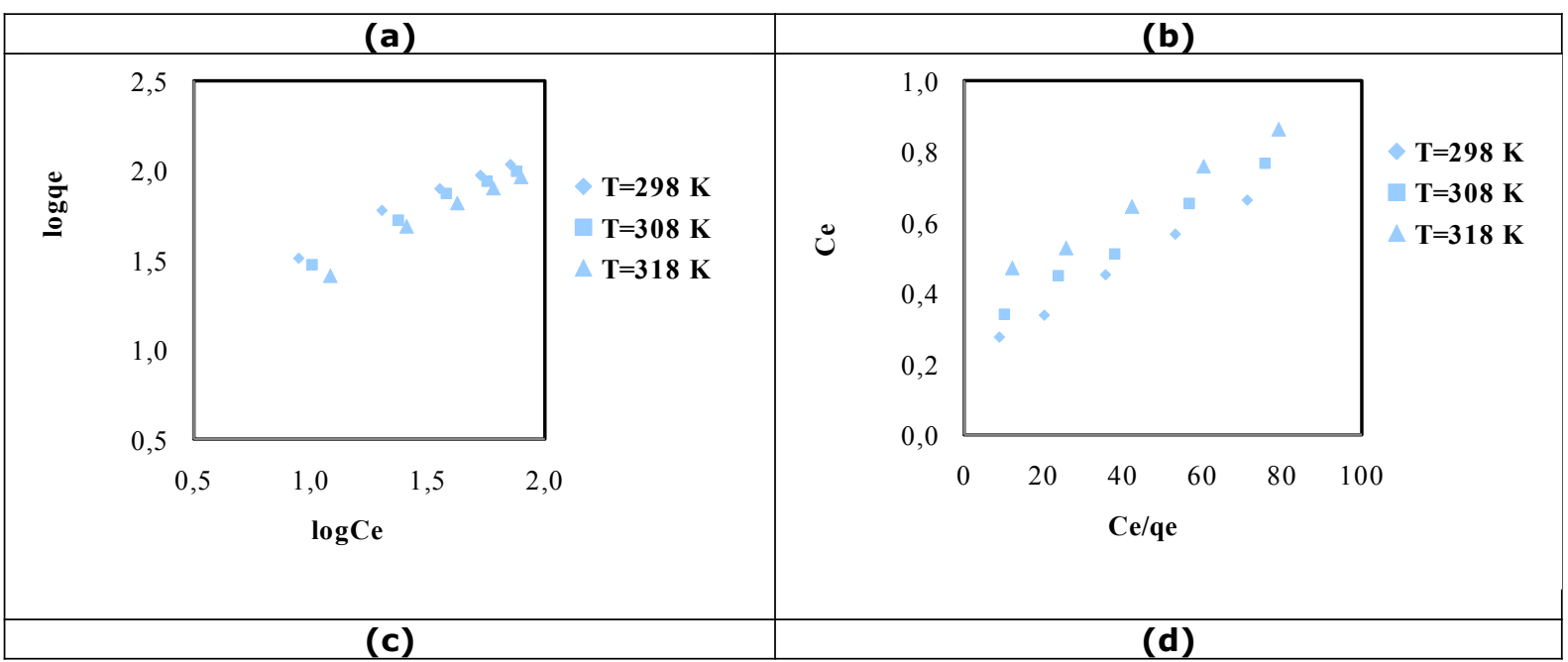

Figure 5: (a) Pseudo-first-order, (b) pseudo-second-order kinetic studies; (c) Langmuir, (d) Freundlich adsorption isotherms of MG dye on PMMAC-MIC.

Table 3: Isotherm data for the adsorption of MG dye onto PMMAC-MIC.

\begin{tabular}{|c|c|c|c|c|c|c|c|}
\hline \multirow{2}{*}{$\mathrm{T}(\mathrm{K})$} & \multicolumn{4}{|c|}{ Langmuir isotherm } & \multicolumn{3}{|c|}{ Freundlich isotherm } \\
\hline & $\begin{array}{c}Q_{\max } \\
(\mathrm{mg} / \mathrm{g})\end{array}$ & $\begin{array}{c}K_{L} \\
(\mathrm{~L} / \mathrm{mg})\end{array}$ & $R_{L}$ & $R^{2}$ & $\begin{array}{c}1 / n \\
(\mathrm{mg} / \mathrm{g})\end{array}$ & $\begin{array}{c}K_{F} \\
(\mathrm{mg} / \mathrm{g}) \stackrel{(\mathrm{L} / \mathrm{mg})^{1 / r}}{ }\end{array}$ & $R^{2}$ \\
\hline 298 & 166.67 & 0.027 & 0.121 & 0.9969 & 0.57 & 9.87 & 0.9832 \\
\hline 308 & 156.85 & 0.023 & 0.122 & 0.9951 & 0.60 & 7.64 & 0.9880 \\
\hline 318 & 155.25 & 0.016 & 0.123 & 0.9963 & 0.67 & 5.09 & 0.9875 \\
\hline
\end{tabular}

Free energy $\left(\Delta G^{\circ}\right)$, enthalpy $\left(\Delta H^{\circ}\right)$, and entropy $\left(\Delta S^{\circ}\right)$ of adsorption which are known as thermodynamic parameters were calculated to investigate the temperature effect on the adsorption of MG dye by the PMMAC-MIC composite. The following equation is used for the calculation of thermodynamic parameters (Eq. 9,10).

$$
\begin{gathered}
\log K_{L}=-\Delta H^{0}(2.303 \times R) \times T+\Delta S^{0}(2.303 \times R) \\
\Delta G^{0}=R \times T \times \ln K_{L}
\end{gathered}
$$

Where $K$ is the equilibrium constant ratio of adsorbate on the adsorbent, $R(8.314 \mathrm{~J} / \mathrm{mol} \mathrm{K})$ is the molar gas constant and $T(\mathrm{~K})$ is the temperature.

The adsorption experiments were conducted at three temperatures $(298,308,318 \mathrm{~K}$ ) and the plot of $\ln K_{L}$ vs. $1 / T$ using the first above equation was drawn (not shown). Also, slope and intercept of the linear plot give values of $\Delta H^{\circ} / R$ and $\Delta S^{\circ} / R$, respectively. Table 4 represented the calculated results of the thermodynamic parameters. According to Table 4, negative values of $\Delta G^{\circ}$, the positive value of $\Delta H^{\circ}$, and the positive value of $\Delta S^{\circ}$ demonstrate the spontaneous, endothermic, and favorable adsorption reaction of $M G$ dye on the surface of the PMMAC-MIC adsorbent, respectively.

Table 4: Thermodynamic parameters of MG dye adsorption onto PMMAC-MIC._

\begin{tabular}{cccc}
$T(\mathrm{~K})$ & $\Delta G(\mathrm{~kJ} / \mathrm{mol})$ & $\Delta H(\mathrm{~kJ} / \mathrm{mol})$ & $\Delta S(\mathrm{~kJ} / \mathrm{molK})$ \\
\hline 298 & -8.02 & & \\
308 & -7.81 & 22.36 & 93.94 \\
318 & -7.21 & & \\
\hline
\end{tabular}

Due to the values of $\Delta G$ are between 20 and 0 $\mathrm{kJ} / \mathrm{mol}$, the adsorption mechanism is called physisorption (while $80-400 \quad \mathrm{~kJ} / \mathrm{mol}$ is chemisorption) (41).

\section{Regeneration of the Composite}

In the case of the regeneration experiments, $\mathrm{HCl}$ eluent was used for desorption and reused to adsorb the MG dye with four adsorption cycles. Figure 4d shows that the adsorption capacity of MG was 93.80 $\mathrm{mg} / \mathrm{g}$ in the first cycle and was $82.20 \mathrm{mg} / \mathrm{g}$ after four cycles on PMMAC-MIC adsorbent. This slight reduction indicates that the PMMAC-MIC composite is stable and can be reutilized several times with good productivity in adsorption capacity for MG dye.

\section{Selectivity Analysis}

PMMAC-MIC composite was researched for the selective binding with $M G$ dye. Hence, the adsorption performance of $\mathrm{MB}, \mathrm{RO} 16$, and $\mathrm{AB} 25$ dyes was performed for reusability of PMMAC-MIC adsorbent towards MG dye as utilized in Figure 4e. It was seen that MG dye showed the best binding performance and adsorption capacity, $93.78 \mathrm{mg} / \mathrm{g}$ 
while the adsorption capacity was $36.11 \mathrm{mg} / \mathrm{g}$, $15.20 \mathrm{mg} / \mathrm{g}$, and $12.55 \mathrm{mg} / \mathrm{g}$ for RO16, MB, and $A B 25$, respectively. As a result, the imprinting method selectively detects the MG dye, thereby effectively improving its adsorption performance through selective bonding points.

\section{CONCLUSION}

It was found that PMMAC-MIC composite obtained by the imprinting method increased MG adsorption capacity. The average particle size of PMMAC-MIC and PMMAC-NIC was obtained by Zeta potential as $449.0 \mathrm{~nm}$ and $860.3 \mathrm{~nm}$, respectively. Also, the results from the XRD analysis revealed that the crystalline size of PMMAC-MIC and PMMA-NIC was $9.50 \mathrm{~nm}$ and $11.0 \mathrm{~nm}$, respectively. According to the adsorption performance, reusability has been determined four times. DSC and TGA analyses showed that the thermal stability of MIC was better than NIC confirming the successful imprinting dye ions. The adsorption of MG dye was described well with pseudo-first-order kinetic model, suggesting that physical adsorption processes by quite a low surface coverage. According to calculations of thermodynamic parameters, the adsorption mechanism can be called a spontaneous reaction resulting from negative $\Delta G^{\circ}$ values. Due to the small value of $\Delta G^{\circ}(7.2-8.1 \mathrm{~kJ} / \mathrm{mol}<80 \mathrm{~kJ} / \mathrm{mol})$, the adsorption reaction can be described as physisorption. The positive value of $\Delta H^{\circ}$ indicated endothermic adsorption; therefore, higher temperatures will facilitate the adsorption of MG dye by PMMAC-MIC adsorbent interface while the positive value of $\Delta S^{\circ}$ verified the favorability. The results represented the monolayer adsorption process and the maximum monolayer adsorption capacity was found as $93.78 \mathrm{mg} / \mathrm{g}$. Indeed, regeneration experiments indicated that the molecular imprinting method for MG adsorption is very suitable for adsorption and PMMAC-MIC can be used as an efficient and selective adsorbent for the treatment of dyes from aqueous solutions when compared to the previous studies. Due to this favorable performance for $M G$, it is promising that this imprinting composite may be applied to remove other dyes. Also, this study is expected to improve chromatographic adsorbents, sensors, membranes, enzyme, and receptor mimetic areas by molecular imprinting method, with the development of higher capacity adsorbents.

\section{REFERENCES}

1. Yildirim A, Acay $H$. Biosorption Studies of Mushrooms for Two Typical Dyes. JOTCSA. 2020; 7(1): 295-306.
2. Zhang $Y$, Huang $Y$, Zhai $F$, Du $R$, Liu $Y$, Lai $K$. Analyses of enrofloxacin, furazolidone and malachite green in fish products with surface-enhanced Raman spectroscopy. Food Chemistry. 2012; 13: 845-50.

3. Li Q, Su H, Li J, Tan T. Application of surface molecular imprinting adsorbent in expanded bedfor the adsorption of $\mathrm{Ni}^{2+}$ and adsorption model. Journal of Environmental Management. 2007; 85: 900-7.

4. Hui $Y$, Yan-Fei C, Hui-Qin G, Wen-Tian $M$, Jing $L$, Shui-Gen Z, Sen L, Liu-Shui Y, Ke-Xin L. Preparation of Molecularly Imprinted Carbon Microspheres by One-Pot Hydrothermal Method and Their Adsorption Properties to Perfluorooctane Sulfonate. Chinese Journal of Analytical Chemistry. 2019; 47: 1776-84.

5. He Q, Liang JJ, Chen LX, Chen SL, Zheng HL, Liu $\mathrm{HX}$, Zhang HJ. Removal of the environmental pollutant carbamazepine using molecular imprinted adsorbents: Molecular simulation, adsorption properties, and mechanisms. Water Research. 2000; 168: 1151642, 1-13.

6. Yi Z, Huajie L, Mingchun L, Meihua X. Adsorption of aniline on aminated chitosan/graphene oxide composite material. Journal of Molecular Structure. 2020; 1209: 127973, 1-6.

7. Wang R, Zhang X, Zhu J, Bai J, Gao L, Liu S, Ji T. Facile preparation of self-assembled chitosan-based composite hydrogels with enhanced adsorption performances. Colloids and Surfaces A: Physicochemical and Engineering Aspects. 2020; 598: $124860,1-9$.

8. Deng $H$, Wei Z, Wang XN. Enhanced adsorption of active brilliant red $\mathrm{X}-3 \mathrm{~B}$ dye on chitosan molecularly imprinted polymer functionalized with Ti(IV) as Lewis acid. Carbohydrate Polymers. 2017; 157: 1190-7.

9. Kyzas GZ, Lazaridis NK, Bikiaris DN. Optimization of chitosan and $\beta$-cyclodextrin molecularly imprinted polymer synthesis for dye adsorption. Carbohydrate Polymers. 2013; 91: 198-208.

10. MR Fat'hi, S.J.H. Nasab. Synthesis of calconimprinted magnetic chitosan nanoparticles as a novel adsorbent and its application in selective removal of calcon dye from aqueous solutions. International Journal of Biological Macromolecules. 2018; 114: 1151-60.

11. Ahmed MA, Abdelbar NM, Mohamed AA. Molecular imprinted chitosan- $\mathrm{TiO}_{2}$ nanocomposite for the selective removal of Rose Bengal from wastewater, International Journal of Biological Macromolecules. 2018; 107: 1046-53.

12. da Silva RC, de Aguiar SB, da Cunha PLR, de Paula RCM, Feitosa JPA. Effect of microwave on the 
synthesis of polyacrylamide-g-chitosan gel for azo dye removal. Reactive and Functional Polymers. 2020; 148: 104491, 1-10.

13. Khajavian M, Salehi E, Vatanpour V. Chitosan/polyvinyl alcohol thin membrane adsorbents modified with zeolitic imidazolate framework (ZIF-8) nanostructures: Batch adsorption and optimization. Separation and Purification Technology. 2020; 241: 116759, 1-16.

14. Fan L, Zhang Y, Li X, Luoa C, Lu F, Qiu H. Removal of alizarin red from water environment using magnetic chitosan with Alizarin Red as imprinted molecules. Colloids and Surfaces B: Biointerfaces. 2012; 91: 250-7.

15. Baran, MF Acay H, C Keskin. Determination of antimicrobial and toxic metal removal activities of plant-based synthesized (Capsicum annuum L. Leaves), Ecofriendly, Gold Nanomaterials. Global challenges. 2020; 1900104: 1-7.

16. Bhomick CP, Supong A, Baruah MC, Sinha D. Pine Cone biomass as an efficient precursor for the synthesis of activated biocarbon for adsorption of anionic dye from aqueous solution: Isotherm, kinetic, thermodynamic and regeneration studies. Sustainable Chemistry and Pharmacy. 2018; 10. 419.

17. Acay $\mathrm{H}$, Baran MF. Biosynthesis and characterization of silver nanoparticles using king oyster (Pleurotus eryngii) extract: effect on some microorganisms. Applied Ecology And Environmental Research. 2019; 17: 9205-14.

18. Baran MF, Acay $H$. Antimicrobial Activity of Silver Nanoparticles Synthesized with Extract of Tomato plant Against Bacterial and Fungal Pathogens. Middle Black Sea Journal of Health Science. 2019; 5: 67-73.

19 Yildirim A, Acay H, Baran F. Synthesis and characterisation of mushroom-based nanocomposite and its efficiency on dye biosorption via antimicrobial activity. International Journal of Environmental Analytical Chemistry. 2020; $1739664,1-18$.

20. Baran MF, Yildirim A, Acay H, Keskin C, Aygun $\mathrm{H}$. Adsorption performance of Bacillus licheniformis $\mathrm{sp}$. bacteria isolated from the soil of the Tigris River on mercury in aqueous solutions. International Journal of Environmental Analytical Chemistry. 2020; 1746779, 1-16.

21. Yildirim A, Bulut Y. Adsorption behaviors of malachite green by using crosslinked chitosan/polyacrylic acid/bentonite composites with different ratios. Environmental Technology \& Innovation. 2020; 7: 100560, 1-13.
22 Rajabi M, Mahanpoor K, Moradi O. Preparation of PMMA/GO and PMMA/GO- $\mathrm{Fe}_{3} \mathrm{O}_{4}$ nanocomposites for malachite green dye adsorption: Kinetic and thermodynamic studies. Composites Part B. 2019; 167: 544-55.

23 Labidi A, Salaberria AM, Labidi J, Abderrabba M. Preparation of novel carboxymethyl chitosan-graftpoly(methylmethacrylate) under microwave irradiation as a chitosan-based material for $\mathrm{Hg}^{2+}$ removal. Microchemical Journal. 2019; 148: 53140.

24. Kumari S, Khan AA, Chowdhury A, Bhakta AK, Hussain ZMS. Efficient and highly selective adsorption of cationic dyes and removal of ciprofloxacin antibiotic by surface modified nickel sulfide nanomaterials: Kinetics, isotherm, and adsorption mechanism. Colloids and Surfaces A: Physicochemical and Engineering Aspects. 2020; 586: $124264,1-15$.

25. Bhatti HN, Safa Y, Yakout SM, Shair OH, Iqbalf M, Nazir A. Efficient removal of dyes using carboxymethyl cellulose/alginate/polyvinyl alcohol/rice husk composite: Adsorption/desorption, kinetics and recycling studies. International Journal of Biological Macromolecules. 2020; 150: 861-70.

26. Yang K., Dang H, Liu L, Hu X, Li X, Ma Z, Wang $X$, Ren $T$. Effect of syringic acid incorporation on the physical, mechanical, structural and antibacterial properties of chitosan film for quail eggs preservation, International Journal of Biological Macromolecules. 2019; 141: 876-84.

27. Habiba U, Siddique TA, Lee JJL, Joo TC, Afifi AM. Adsorption study of methyl orange by chitosan/polyvinyl alcohol/zeolite electrospun composite nanofibrous membrane. Carbohydrate Polymers. 2018; 191: 79-85.

28. Boggione MJ, Mahl CRA, Beppu MM, Farruggia B. Synthesis and characterization of chitosan membranes functionalized with amino acids and copper for adsorption of endoglucanase, Powder Technology. 2017; 315: 250-7.

29. Zhang H, Omer AM, Hu Z, Yang LY, Ji C, Ouyang $X K$ Fabrication of magnetic bentonite/carboxymethyl chitosan/sodium alginate hydrogel beads for $\mathrm{Cu}$ (II) adsorption. International Journal of Biological Macromolecules. 2019; 135: 490-500.

30. Lewandowska K, Furtos G. Study of apatite layer formation on SBF-treated chitosan composite thin films. Polymer Testing. 2018; 71: 173-81.

31. Yekeen N, Padmanabhan E, Idris AK, Ibad SM. Surfactant adsorption behaviors onto shale from 
Malaysian formations: Influence of silicon dioxide nanoparticles, surfactant type, temperature, salinity and shale lithology. Applied Clay Science. 2016; 123: 64-75.

32. Awokoya KN, Oninla VO, Babalola JO, Mbaeyi NN, Folorunso FT. Adsorption of malachite green onto styrene-methacrylate based molecularly imprinted polymer. Ife Journal of Science. 2019; 21: 67-80.

33. Farhadia K, Matin AA, Hashemia P. Removal of malachite green from aqueous solutions using molecularly imprinted polymer. Desalination and Water Treatment. 2010; 24: 20-7.

34. Yildirim A. Kinetic, equilibrium and thermodynamic investigations for the bio-sorption of dyes onto crosslinked Pleurotus ostreatus-based bio-composite. International Journal of Environmental Analytical Chemistry. 2020; $1802441,1-16$.

35. Banerjee D, Bhowmick P, Pahari D, Santra S, Sarkar S, Chattopadhyay BDKK. Pseudo-first ordered adsorption of noxious textile dyes by lowtemperature synthesized amorphous carbon nanotubes. Physica E. 2017; 87: 68-76.

36. Robati D, Rajabi M, Moradi O, Najafi F, Tyagi I, Agarwal S, Gupta VK. Kinetics and thermodynamics of malachite green dye adsorption from aqueous solutions on graphene oxide and reduced graphene oxide. Journal of Molecular Liquids. 2016; 214: 259-63.

37. Shang $Y$, Shi $Y C R$, Yang $P$, Wang J, Wang $Y$. Regenerated $\mathrm{WO}_{2.72}$ nanowires with superb fast and selective adsorption forcationic dye: Kinetics, isotherm, thermodynamics, mechanism. Journal of Hazardous Materials. 2019; 379: 120834, 1-10.

38. Bonetto LR, Ferrarini F, Marco CD, Crespo JS, Ruégan $R$, Giovanela $M$. Removal of methyl violet 2B dye from aqueous solution using a magnetic composite as an adsorbent. J. Water Process Eng. 2015; 6: 11-20.

39. De Castro MLFA, Abad MLB, Sumalinog DAG, Abarca RRM, Paoprasert $P$, de Luna MDG. Adsorption of Methylene Blue dye and $\mathrm{Cu}$ (II) ions on EDTA-modified bentonite: Isotherm, kinetic and thermodynamic studies. Sustainable Environment Research. 2018; 28: 197-205.

40. Dastgerdi ZH, Abkhiz V, Meshkat SS, Ghorbana $\mathrm{N}$. Preparation of novel magnetic grafted raft agent nanocomposite: Application in carmine dye adsorptive removal from waste water. Journal of Environmental Chemical Engineering. 2019; 7: 103109, 1-9.

41. Wang L, Zhang J, Wang A. Fast removal of methylene blue from aqueous solution by adsorption onto chitosan-g-poly (acrylic acid)/attapulgite composite. Desalination. 2011; 266: 33-9. 